\title{
Cultural Influences on Maternal and Child Health in Singkil District, Aceh, Indonesia
}

\author{
Amandha B.T. Randita ${ }^{1 *}$, Fitriana ${ }^{2}$, Daniel R. Kambey ${ }^{3}$, Ayuningtyas S. Lestari ${ }^{4}$ and \\ Onishi $\mathrm{H}^{3}$ \\ ${ }^{I}$ Medical Education Department, Faculty of Medicine Universitas Sebelas Maret, Indonesia, \\ ${ }^{2}$ Community and Family Medicine Department Faculty of Medicine, Public Health and Nursing Universitas \\ GadjahMada, Indonesia \\ ${ }^{3}$ Department of International Cooperation for Medical Education, School of International Health, The \\ University of Tokyo, Japan \\ ${ }^{4}$ Depati Hamzah General Hospital, Pangkalpinang, Bangka Belitung Indonesia \\ Corresponding Authors'Email: *boy.timor@staff.uns.ac.id
}

\begin{abstract}
Maternal and child health $(\mathrm{MCH})$ mortality continues to be a serious problem worldwide. Most maternal deaths occur in developing countries especially in rural areas; the majority of child health challenges occur in the first five years of life. Aceh province has one of the highest maternal and child mortality rates in Indonesia. The Singkil district in this area has cultural influences that affect $\mathrm{MCH}$. Called Badapu practices, these include food and water restriction for post-partum women, and restriction to small, smoke-filled rooms to ensure their bodies stay warm and fresh. Negative impacts of these cultural practices are malnutrition, anemia, and reduced breast milk production in postpartum women; reduced growth and development, and high risk for respiratory tract infection for babies. All of these contribute to mortality and morbidity. Addressing these cultural practices is necessary to improve maternal and child health. Stakeholders should consider collaboration in Badapu with shamans and midwives to negotiate positive behavioral change.
\end{abstract}

Keywords: Badapu, cultural influence, collaboration practice, maternal and child health

\section{Introduction}

The World Health Organization defines maternal health as the health of women during pregnancy, childbirth, and post-partum periods. Maternal health practices include the activities or habits of women throughout these periods, which impact to their health. Every day, approximately 830 women die from preventable causes, with $99 \%$ of maternal deaths happening in developing countries and in rural and poor communities there (World Health Organization, 2018). Child health is also a serious problem worldwide, with the majority of child health morbidity and mortality occurring in the first five years of life, and over half among newborns (World Health Organization, 2018). Children represent the most vulnerable segment of society and childhood illness contributes substantially to the global burden of disease. The majority of childhood deaths are preventable or treatable with currently available intervention (Denno \& Stewart, 2013).

Singkil district is a district in Aceh Province, Indonesia. Data from the Health District Office stated that the province has one of highest maternal and child mortality rates in Indonesia (Koto et al. 2018). In the period 2011-2014, maternal and neonatal/infant death in Singkil District increased each year. For mothers, this increase occurred in the post-partum period; for children, the increase was the result of low birth weight, asphyxia, pneumonia, and diarrhea (Dinas Kesehatan Kabupaten Aceh Singkil 
2015). A maternal and child health (MCH) study of the Singkil District found the increases to be directly related to pre-eclampsia, infection, and hemorrhage.

Few studies have focused on socio-cultural factors such as MCH-related beliefs and traditions. An understanding of these beliefs and traditions is particularly important in designing culturally appropriate interventions (Morris et al. 2014b). This study reports on MCH cultural influence related to Badapu culture in Singkil District.

\section{Methods}

This was a qualitative study conducted in July 2019 to explore influences of "Badapu" culture on $\mathrm{MCH}$ in Singkil District. Researchers conducted in-depth interviews with women providing care to postpartum women to and stakeholders from primary healthcare and health district offices. An interview guide was developed by the research team to achieve the goals of the study. Interviews were recorded, transcribed, and re-checked. Inductive content analysis was performed to identify themes in the data. Verbal informed consent was obtained from each study participants. The identity of each participant was kept confidential. The research received permission from Indonesian Ministry of Village, Development of Disadvantaged Regions, and Transmigration.

\section{Results}

Badapu is a hereditary cultural tradition that believes in food restriction for postpartum women, while warming the woman and the baby in a room full of smoke. Mothers and their babies have to participate in Badapu for 40 until 60 days.

“... Every woman after giving birth they only consume rice with little water. They also cannot consume any vegetable and fruits. We believe that chicken, meat and water make delay in wound healing" (Participant 1, Family of woman after giving birth).

Badapu tradition also believes that the mother and her baby have to live in a small room full of smoke and not go anywhere. The woman should lay down in a bed with hot stones on her feet, and should not raise their arms. This position is supposed to make sure all of the woman's body will stay warm.

"We believe that woman who sweaty will make their wound related to giving birth will healed. Every woman and her child will stay in a small room to warm up our body. We also restrict theirselfcare such as take a bath to make sure our body still sweaty" (Participant 2, Woman).

Badapu culture affects the quality of $\mathrm{MCH}$. Side effects of Badapu include discontinuation of breastfeeding, which makes malnutrition of the baby. It is believed that the newborns and infants living in the small room full of smoke from the firebox to warm their bodies will have a positive impact on their respiratory tract. However, these same newborns and infants will be at risk for respiratory tract infection and pneumonia that can cause the high mortality in Singkil District. 
"Badapu is one of the contributing factors related to high maternal and child mortality in Singkil District. Women have high risk for anemia related to food restriction and the baby is at risk for respiratory tract infection" (Participant 3, Local Development Officer).

Stakeholders in Singkil District such as health district office and local development office stated that they have a program to minimalize health impacts related to the Badapu tradition.

"Our government motivates collaboration among midwife and local shaman to improve MCH. We make memorandum of understanding (MoU) to increase awareness of health behavior" (Participant 4, Midwife)

\section{Discussion}

This study describes Badapu as a culture related to $\mathrm{MCH}$ in Singkil District. Badapu is a culture which involves food restriction for post partum women and need for women to live in a small room that full of smoke. Women only eat rice and consume a small amount of water. They believe that this culture will help women to feel resh after giving birth (Badan Perencanaan Pembangunan Daerah, 2016).

Badapu requires food restriction for post-partum women that affects their nutritional status. Postpartum women who intake less nutrition are at risk for anemia. A study byDeri (2009) found that $82.2 \%$ of subjects in the area had anemia, with average hemoglobin $(\mathrm{Hb})$ level of $9.01 \pm 1.48 \mathrm{gr} / \%$. Over two-thirds (68.9\%) of the post-partum women involved in Badapu had a body mass index (BMI) under 25, with a statistically significant relationship with intake, $\mathrm{Hb}$ and BMI. This lack of nutrition delays the wound healing process, which requires high protein for fibrinogen formation, not protein restriction. Post-partum women also need increased nutrition for adequate breastfeeding. The baby needs breast milk as an important nutrition source. Low intake of breast milk for babies means that they lack an important source of nutrition, which has a negative impact on growth and development. Finally, the mother and baby in Badapu culture living in a room full of smoke from firewood means that exposure to carbon monoxide from the smoke leads to low oxygen levels (Badan Perencanaan Pembangunan Daerah 2016).

Badapu cultural practices such as described in this study are similar in Madagascar, which considers pregnancy and childbirth to be dangerous times for woman. Practices with postpartum women there seek to clean dirty blood by using hot water to promote healing and return the body to pre-pregnancy state, minimizing movement, and restricting bathing. These maternal practices are supporte by family and community members (Morris, Short, Robson, \& Andriatsihosena, 2014).

\section{Conclusion}

The sociocultural environment of a community can have both positive and negative effects because of the relationship between health and culture. Culture affects behavior and responses related to health and disease. Health care providers have an important role in changing unhealthy behaviors and can negotiate and modify the culture (Rahayu et al. 2017). Local stakeholders can reduce negative impacts of Badapu by making collaborative agreements between shamans and midwives in order to negotiate 
positive behavioral change. Such a collaborative process can result in a shared vision of patientcentered care.

\section{Acknowledgment and Conflict of Interest}

The research team members declare that we do not have any conflict of interest

\section{References}

Badan Perencanaan Pembangunan Daerah, 2016. Kajian Faktor Resiko Kematian Ibu dan Bayi.

Bakke, H.K., 2017. First-aid training in school: amount, content and hindrances. Acta Anaesthesiologica Scandinavia, 61, pp.1361-1370.

Dinas Kesehatan Kabupaten Aceh Singkil, 2015. Profil kesehatan kabupaten aceh singkil. , (55).

Koto, E., Andriani, L. \& Ginting, R., 2018. Kompetensi Komunikasi Kemitraan Bidan Desa dan Dukun Bayi dalam Mendukung Penurunan Angka Kematian Ibu dan Bayi. Jurnal Ilmiah Kajian Politik Lokal dan Pembangunan, 4, pp.26-36.

Morris, J.L. et al., 2014a. Maternal Health Practices , Beliefs and Traditions in Southeast Madagascar. , 18(September), pp.101-117.

Morris, J.L. et al., 2014b. Maternal Health Practices, Beliefs and Traditions in Southeast Madagascar Maternal Health Practices , Beliefs and Traditions in Southeast Madagascar. , (October).

Parreira, S.F., 2018. Dimensions of interprofessional work and of collaborative practices developed at a primary care unit by a Family Health team. , 22, pp.1717-1728.

Rahayu, I.S. et al., 2017. Faktor Budaya Dalam Perawatan Ibu Nifas Cultural Factors In Treatment In The Postpartum Mother desa yang sederhana dapat bertahan dengan. , 3. 